\title{
Load of HeteLoad of Heterotrophicrotrophic and Nitrifying Bacteria in the Sewage Lagoon and the Receiving River Buriganga
}

\author{
Mehedi Mahmudul Hasan ${ }^{1}$, M Kawser Ahmed ${ }^{1 *}$, Fauzia Hafiz², Abu Muhammad Imtiaz Hussain², Sahana Parveen² \\ and Shiuly Rahman Tinni ${ }^{1}$ \\ ${ }^{1}$ Department of Fisheries, University of Dhaka, Dhaka 1000, Bangladesh, ${ }^{2}$ Food Microbiology Lab., Institute of Food Science \& Technology (IFST), \\ Bangladesh Council of Scientific \& Industrial Research (BCSIR), Dr Qudrat-e-Khuda Road, Dhaka 1205, Bangladesh
}

\section{[Received 07 April 2006; Accepted 07 October 2006]}

\begin{abstract}
The present study was undertaken to investigate the prevalence of some selected heterotrophic bacteria in one of the sewage lagoons and in the river Buriganga, which receives the sewage effluents from the sewage lagoons, with a view to evaluate the effect of sewage treatment. The heterotrophic plate count (HPC) ranged from $1.1 \times 10^{8}$ to $3.0 \times 10^{9} \mathrm{cfu} / \mathrm{ml}$ in sewage lagoon from January to December 2005. The HPC values ranged from $1.1 \times 10^{5}$ to $3.0 \times 10^{9} \mathrm{cfu} / \mathrm{ml}$ in the outfall of the sewage effluents and other sampling locations in the river Buriganga. The total and faecal coliform counts of the sewage lagoon and the discharge point in the river were always very high as $>2.4 \times 10^{3} \mathrm{cfu} / 100 \mathrm{ml}$ in all seasons as measured by the MPN method. Salmonellae were isolated occasionally, while vibrios were frequently isolated from all the sampling points from throughout the year. The MPN values of nitrifying bacteria were also estimated to compare with HPC values. Ammonium oxidizers ranged from $1.1 \times 10^{2}$ to $1.1 \times 10^{3} / \mathrm{ml}$ in the sewage lagoon and $2.0 \times 10^{1}$ to $2.2 \times 10^{3} / \mathrm{ml}$ in the river water. Nitrite oxidizers showed very low MPN values. This study suggests that the water of the river Buriganga was heavily polluted. It also suggests that the oxidation or self-purification system in the oxidation lagoons and subsequent treatment of the effluents were far from satisfactory level. Even the discharged sewage in the river Buriganga remains equally contaminated, which had been demonstrated by the presence of large number of pathogenic organisms. This poses health hazards to the users of the water from the river and also poses risks for the aquatic organisms of this water body.
\end{abstract}

Keywords: Sewage lagoon, Buriganga River, Heterotrophic bacteria, Coliform bacteria Salmonella, Vibrio, Nitrifying bacteria

\section{Introduction}

Sewage is a major household waste. It is wastewater, including human excrement and wash waters everything that goes down the drains of a home and into a sewerage system. The wastewater of a city is collected through a sewerage system, which carries the used water to its ultimate point of treatment and disposal. Untreated or improperly treated sewage effluents pollute surface waters ${ }^{1}$. Sewage is one of the main sources of water pollution. It contains many organic and inorganic constituents and microorganisms. They are potential hazards for the aquatic organisms and human beings. If they are allowed to mix with river and seawater without proper treatment, this may pose a threat for the living being of water and other consumers. Release of untreated wastewater into the near-shore environment for decades has the potential to degrade the environment ${ }^{2}$, infect indigenous species ${ }^{3}$, and contaminate source water for the potable system of the station ${ }^{4}$. From a microbiological perspective this has perhaps the most extensive impact on community structure, eutrophication, and oxygen demand.
The capital city Dhaka generates a huge quantity of sewage everyday. The sewage treatment plant of the city is located at a place called Pagla. The place is not far from the metropolis and lies at the bank of the river Buriganga. In Dhaka city, the sewage largely consists of wastewater from toilet because the system was designed so. Pagla Sewage Treatment Plant (PSTP) was designed to treat a maximum flow of $120,000 \mathrm{~m}^{3} /$ day of domestic sewage generated from about $18 \%$ population of the metropolitan ${ }^{5}$. There has always been a general complaint of shortcomings of the overall performance of the plant. The effluents contain large numbers of heterotrophic bacteria, organic matter, and ammonium and are a source of pathogenic and nitrifying bacteria. As a result, degradation of organic matter and subsequent oxygen depletion occur immediately downstream of the effluent outlet, whereas nitrifying bacteria apparently need to build up a significant biomass before ammonium oxidation significantly depletes the oxygen ${ }^{6}$. The Buriganga River downstream is greatly affected by the discharge of these effluents. A typical feature of the ecological functioning of any river is an oxygen deficit immediately downstream of the effluent outlet due

*Corresponding author:

Dr. $M$ Kawser Ahmed, Chairman, Department of Fisheries, University of Dhaka, Dhaka 1000, Bangladesh

Tel (Office): (02) 9661920-73/7775, 7779; Tel (Home): (02) 8014273; Cell: 0152 371374; Fax: +880 (02) 8615583; E-mail: kawser_du@yahoo.com 
to degradation of organic matter and another depletion in the river due to nitrification of ammonium that is also contained in the effluent.

With the increase in the interest in the microbial ecology of aquatic environments in recent years, it is important to have an understanding of the natural, or autochthonous, microbial flora. Since the bacteria are well known agents of mineralization and transformation of organic and inorganic matters in aquatic ecosystem, it was considered useful to determine the prevalence of some selected heterotrophic bacteria in the river Buriganga.

\section{Materials and Methods}

\section{Sampling sites and sampling period}

Sample waters were obtained from one of the lagoons of the Pagla Sewage Treatment Plant, the out fall point of the sewage effluents in the Buriganga River, four downstream non-point sampling locations of the river and from one upstream location to the outfall (Figure 1). The first downstream sampling point was Munshikhola, which is $0.5 \mathrm{~km}$ away from the sewage outfall in the Buriganga River. The second downstream sampling point was located in the site of the Paglabazar, which is $1.5 \mathrm{~km}$ far from the sewage outfall in the Buriganga River. The third downstream location in the Buriganga River was $2.5 \mathrm{~km}$ away from the sewage outfall, which is located in Aliganj. The fourth downstream sampling point was $3.5 \mathrm{~km}$ away from the outfall in the region of Fatullah in the Buriganga River. Samples were collected during January to December in 2005 to analyse the monthly variation of bacteriological analysis. The number of nitrifying bacteria was estimated from the samples collected only in the months of February, May and September 2005.

\section{Determination of physicochemical factors}

The physicochemical factors were determined by standard methods ${ }^{7}$. The temperature was recorded by a mercury thermometer gradated between $0^{\circ}$ and $100^{\circ} \mathrm{C}$. $\mathrm{pH}$ of the water samples were determined by a $\mathrm{pH}$ meter. Dissolved oxygen (DO) content of the water samples was determined by a DO Meter.

\section{Bacteriological analyses}

The heterotrophic bacteria were counted by the pour-plate technique ${ }^{7}$. The total and faecal coliform bacteria were enumerated by MPN procedures ${ }^{8}$. Nucleated and metallic shining colonies on eosin methylene blue (EMB) agar plates were suspected as Escherichia coli and IMViC tests were done to differentiate E. coli from other coliforms ${ }^{7}$. Salmonella was enriched and isolated from the sample waters by the method described by APHA ${ }^{7}$. Alkaline peptone water (APW) was used commonly for enrichment and isolation of Vibrio. TCBS agar was also used for plating and incubating the microorganism. Biochemical tests were made to identify the presence of Vibrio in the samples ${ }^{7,9}$. Two media were prepared for quantification of ammonium oxidizers and nitrite oxidizers accordingly. The mineral media for ammonium oxidizers contained $\left(\mathrm{NH}_{4}\right)_{2} \mathrm{SO}_{4}$ as the sole nutrient supply and the mineral media for nitrite oxidizers contained $\mathrm{NaNO}_{2}$ as the sole nutrient supply. The methodology described by Matulewich et al. ${ }^{10}$ was followed for this estimation.

\section{Results and Discussion}

In the sewage lagoon, the temperature ranged from $20.5^{\circ}$ to $32.3^{\circ} \mathrm{C}$, $\mathrm{pH} 7.7$ to 8.5 , dissolved oxygen 7.0 to $8.5 \mathrm{mg} / \mathrm{l}$. In the sewage discharge point of the river and of the downstream and upstream points, temperature varied from $19.0^{\circ}$ to $31.8^{\circ} \mathrm{C}$, $\mathrm{pH} 7.4$ to 8.5 , dissolved oxygen 7.1 to $11.0 \mathrm{mg} / \mathrm{l}$. Due to the presence of oxygendemanding pollutants like organic wastes, there existed a rapid depletion of dissolved oxygen from water. Anoxia (lack of oxygen) or hypoxia (dissolved oxygen concentrations lower than required by indigenous organisms) could be a particular concern in the Buriganga River.

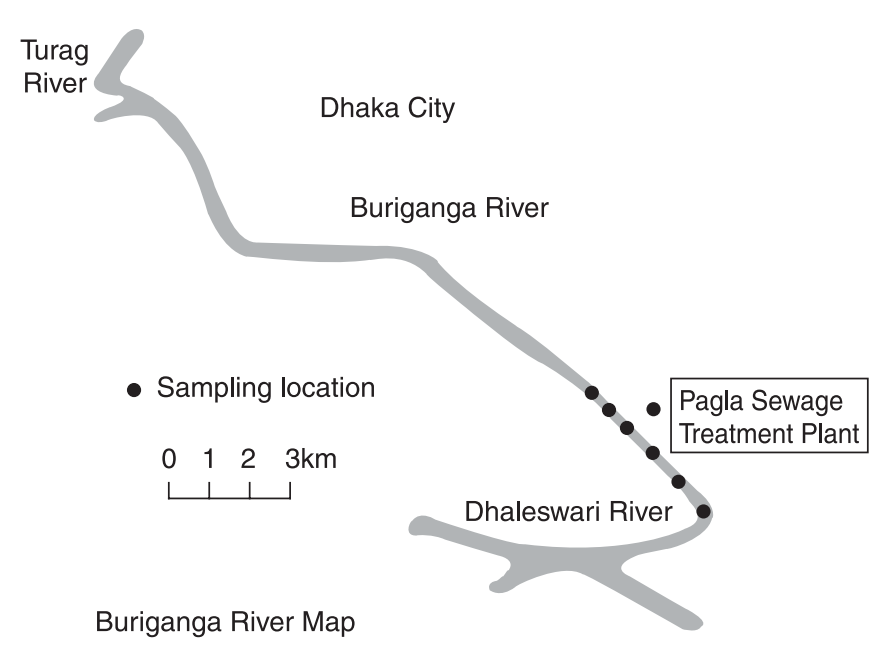

Figure 1. Map of the Buriganga River with different sampling locations.

Even after treatment, domestic effluents are sources not only of chemical compounds but also of microorganisms that can be very active in the river, and they may play a fundamental role in the ecological functioning of the system ${ }^{11}$. It was found that heterotrophic bacterial count ranged from $1.10 \times 10^{8}$ to $3.00 \times 10^{9} \mathrm{cfu} / \mathrm{ml}$ in sewage lagoon. The amount of heterotrophic bacteria varied from $1.10 \times 10^{5}$ to $2.98 \times 10^{9} \mathrm{cfu} / \mathrm{ml}$ in the outfall of the sewage effluents including other sampling locations in the Buriganga River (Table 1). In sewage and river waters the highest heterotrophic bacterial count were observed in the month of March 2005. There was a reasonable variation of these bacteria in all the samples in every month of the year. Despite the fact that heterotrophic bacteria supplied by the effluent can be active in the river immediately downstream of the effluent input, they have been shown to disappear rapidly ${ }^{11-12}$. Our findings on the heterotrophic bacterial count were also in agreement with the findings of Garnier et al. ${ }^{12}$ and Garnier et al. ${ }^{11}$. 
The MPN values for the total coliform counts in sewage lagoon were always $>2.4 \times 10^{3} / 100 \mathrm{ml}$ and that of the different points of the Buriganga River water varied from $1.1 \times 10^{3}$ to $>2.4 \times 10^{3} / 100 \mathrm{ml}$ water (Table 2). The MPN values of the faecal coliform bacteria in sewage lagoon were always $>2.4 \times 10^{3} / 100 \mathrm{ml}$ and the faecal coliform counts of the water of the outfall point and the other locations of the Buriganga River varied from $1.1 \times 10^{3}$ to $>2.4 \times 10^{3} / 100 \mathrm{ml}$ water (Table 3).

Table 1. Month-wise variation of total heterotrophic bacteria in sewage lagoon and at different sampling points of the river Buriganga

\begin{tabular}{|c|c|c|c|c|c|c|c|}
\hline \multirow[t]{2}{*}{ Month } & \multicolumn{6}{|c|}{ Heterotrophic bacterial count (cfu/ml) } & \multirow[b]{2}{*}{ Fatullah } \\
\hline & Dhaleswar & Lagoon & Outfall & Munshikhola & Paglabazar & Aliganj & \\
\hline January & $1.0 \times 10^{6}$ & $1.5 \times 10^{9}$ & $3.0 \times 10^{8}$ & $3.0 \times 10^{7}$ & $2.5 \times 10^{6}$ & $2.4 \times 10^{6}$ & $3.0 \times 10^{5}$ \\
\hline February & $1.7 \times 10^{6}$ & $3.1 \times 10^{8}$ & $3.0 \times 10^{8}$ & $3.0 \times 10^{7}$ & $2.9 \times 10^{6}$ & $2.8 \times 10^{6}$ & $1.1 \times 10^{5}$ \\
\hline March & $3.0 \times 10^{7}$ & $3.0 \times 10^{9}$ & $3.0 \times 10^{9}$ & $2.6 \times 10^{8}$ & $3.1 \times 10^{7}$ & $3.0 \times 10^{8}$ & $2.8 \times 10^{6}$ \\
\hline April & $2.5 \times 10^{6}$ & $2.9 \times 10^{9}$ & $3.0 \times 10^{8}$ & $2.6 \times 10^{7}$ & $3.0 \times 10^{6}$ & $2.1 \times 10^{6}$ & $1.5 \times 10^{6}$ \\
\hline May & $1.8 \times 10^{6}$ & $1.8 \times 10^{8}$ & $1.8 \times 10^{8}$ & $2.1 \times 10^{7}$ & $1.3 \times 10^{7}$ & $1.0 \times 10^{7}$ & $2.3 \times 10^{6}$ \\
\hline June & $1.7 \times 10^{6}$ & $1.4 \times 10^{8}$ & $1.4 \times 10^{7}$ & $1.2 \times 10^{7}$ & $1.9 \times 10^{7}$ & $1.5 \times 10^{6}$ & $2.1 \times 10^{8}$ \\
\hline July & $1.6 \times 10^{6}$ & $1.1 \times 10^{8}$ & $1.2 \times 10^{7}$ & $2.5 \times 10^{7}$ & $1.5 \times 10^{7}$ & $1.6 \times 10^{6}$ & $2.5 \times 10^{5}$ \\
\hline August & $1.7 \times 10^{6}$ & $2.4 \times 10^{8}$ & $2.6 \times 10^{7}$ & $3.0 \times 10^{7}$ & $2.9 \times 10^{6}$ & $1.4 \times 10^{7}$ & $1.9 \times 10^{6}$ \\
\hline September & $1.1 \times 10^{8}$ & $2.1 \times 10^{8}$ & $3.0 \times 10^{7}$ & $2.4 \times 10^{7}$ & $2.1 \times 10^{6}$ & $2.1 \times 10^{6}$ & $2.0 \times 10^{6}$ \\
\hline October & $1.2 \times 10^{6}$ & $1.9 \times 10^{8}$ & $1.5 \times 10^{8}$ & $1.4 \times 10^{7}$ & $1.6 \times 10^{6}$ & $2.1 \times 10^{6}$ & $1.9 \times 10^{6}$ \\
\hline November & $2.4 \times 10^{6}$ & $1.7 \times 10^{8}$ & $1.6 \times 10^{8}$ & $1.7 \times 10^{7}$ & $1.5 \times 10^{8}$ & $1.6 \times 10^{6}$ & $1.1 \times 10^{6}$ \\
\hline December & $2.4 \times 10^{6}$ & $1.6 \times 10^{8}$ & $1.1 \times 10^{8}$ & $1.1 \times 10^{7}$ & $1.5 \times 10^{6}$ & $2.9 \times 10^{6}$ & $1.4 \times 10^{5}$ \\
\hline
\end{tabular}

Table 2. Month-wise distributions of total coliform counts bacteria in sewage lagoon and at different sampling points of the river Buriganga

\begin{tabular}{|c|c|c|c|c|c|c|c|}
\hline \multirow[t]{2}{*}{ Month } & \multicolumn{7}{|c|}{ Total coliform bacteria (MPN/100 ml) } \\
\hline & Dhaleswar & Lagoon & Outfall & Munshikhola & Paglabazar & Aliganj & Fatullah \\
\hline January & $1.1 \times 10^{3}$ & $>2.4 \times 10^{3}$ & $>2.4 \times 10^{3}$ & $>2.4 \times 10^{3}$ & $>2.4 \times 10^{3}$ & $>2.4 \times 10^{3}$ & $1.1 \times 10^{3}$ \\
\hline February & $1.1 \times 10^{3}$ & $>2.4 \times 10^{3}$ & $>2.4 \times 10^{3}$ & $>2.4 \times 10^{3}$ & $>2.4 \times 10^{3}$ & $>2.4 \times 10^{3}$ & $>2.4 \times 10^{3}$ \\
\hline March & $>2.4 \times 10^{3}$ & $>2.4 \times 10^{3}$ & $>2.4 \times 10^{3}$ & $>2.4 \times 10^{3}$ & $>2.4 \times 10^{3}$ & $>2.4 \times 10^{3}$ & $>2.4 \times 10^{3}$ \\
\hline April & $>2.4 \times 10^{3}$ & $>2.4 \times 10^{3}$ & $>2.4 \times 10^{3}$ & $>2.4 \times 10^{3}$ & $>2.4 \times 10^{3}$ & $>2.4 \times 10^{3}$ & $>2.4 \times 10^{3}$ \\
\hline May & $>2.4 \times 10^{3}$ & $>2.4 \times 10^{3}$ & $>2.4 \times 10^{3}$ & $>2.4 \times 10^{3}$ & $>2.4 \times 10^{3}$ & $>2.4 \times 10^{3}$ & $>2.4 \times 10^{3}$ \\
\hline June & $1.1 \times 10^{3}$ & $>2.4 \times 10^{3}$ & $>2.4 \times 10^{3}$ & $>2.4 \times 10^{3}$ & $>2.4 \times 10^{3}$ & $>2.4 \times 10^{3}$ & $1.1 \times 10^{3}$ \\
\hline July & $1.1 \times 10^{3}$ & $>2.4 \times 10^{3}$ & $>2.4 \times 10^{3}$ & $>2.4 \times 10^{3}$ & $>2.4 \times 10^{3}$ & $>2.4 \times 10^{3}$ & $>2.4 \times 10^{3}$ \\
\hline August & $1.1 \times 10^{3}$ & $>2.4 \times 10^{3}$ & $>2.4 \times 10^{3}$ & $>2.4 \times 10^{3}$ & $>2.4 \times 10^{3}$ & $>2.4 \times 10^{3}$ & $1.1 \times 10^{3}$ \\
\hline September & $1.1 \times 10^{3}$ & $>2.4 \times 10^{3}$ & $>2.4 \times 10^{3}$ & $>2.4 \times 10^{3}$ & $>2.4 \times 10^{3}$ & $>2.4 \times 10^{3}$ & $>2.4 \times 10^{3}$ \\
\hline October & $>2.4 \times 10^{3}$ & $>2.4 \times 10^{3}$ & $>2.4 \times 10^{3}$ & $>2.4 \times 10^{3}$ & $>2.4 \times 10^{3}$ & $>2.4 \times 10^{3}$ & $1.1 \times 10^{3}$ \\
\hline November & $>2.4 \times 10^{3}$ & $>2.4 \times 10^{3}$ & $>2.4 \times 10^{3}$ & $>2.4 \times 10^{3}$ & $>2.4 \times 10^{3}$ & $>2.4 \times 10^{3}$ & $>2.4 \times 10^{3}$ \\
\hline December & $>2.4 \times 10^{3}$ & $>2.4 \times 10^{3}$ & $>2.4 \times 10^{3}$ & $>2.4 \times 10^{3}$ & $>2.4 \times 10^{3}$ & $>2.4 \times 10^{3}$ & $1.1 \times 10^{3}$ \\
\hline
\end{tabular}

Table 3. Month-wise distributions of faecal coliform counts bacteria in sewage lagoon and at different sampling points of the river Buriganga

\begin{tabular}{|c|c|c|c|c|c|c|c|}
\hline \multirow[t]{2}{*}{ Month } & \multicolumn{7}{|c|}{ Faecal coliform bacteria (MPN/100 ml) } \\
\hline & Dhaleswar & Lagoon & Outfall & Munshikhola & Paglabazar & Aliganj & Fatullah \\
\hline January & $1.1 \times 10^{3}$ & $>2.4 \times 10^{3}$ & $>2.4 \times 10^{3}$ & $>2.4 \times 10^{3}$ & $>2.4 \times 10^{3}$ & $>2.4 \times 10^{3}$ & $1.1 \times 10^{3}$ \\
\hline February & $1.1 \times 10^{3}$ & $>2.4 \times 10^{3}$ & $>2.4 \times 10^{3}$ & $>2.4 \times 10^{3}$ & $>2.4 \times 10^{3}$ & $>2.4 \times 10^{3}$ & $>2.4 \times 10^{3}$ \\
\hline March & $>2.4 \times 10^{3}$ & $>2.4 \times 10^{3}$ & $>2.4 \times 10^{3}$ & $>2.4 \times 10^{3}$ & $>2.4 \times 10^{3}$ & $>2.4 \times 10^{3}$ & $>2.4 \times 10^{3}$ \\
\hline April & $>2.4 \times 10^{3}$ & $>2.4 \times 10^{3}$ & $>2.4 \times 10^{3}$ & $>2.4 \times 10^{3}$ & $>2.4 \times 10^{3}$ & $>2.4 \times 10^{3}$ & $>2.4 \times 10^{3}$ \\
\hline May & $>2.4 \times 10^{3}$ & $>2.4 \times 10^{3}$ & $>2.4 \times 10^{3}$ & $>2.4 \times 10^{3}$ & $>2.4 \times 10^{3}$ & $>2.4 \times 10^{3}$ & $>2.4 \times 10^{3}$ \\
\hline June & $1.1 \times 10^{3}$ & $>2.4 \times 10^{3}$ & $>2.4 \times 10^{3}$ & $>2.4 \times 10^{3}$ & $>2.4 \times 10^{3}$ & $>2.4 \times 10^{3}$ & $1.1 \times 10^{3}$ \\
\hline July & $1.1 \times 10^{3}$ & $>2.4 \times 10^{3}$ & $>2.4 \times 10^{3}$ & $>2.4 \times 10^{3}$ & $>2.4 \times 10^{3}$ & $>2.4 \times 10^{3}$ & $>2.4 \times 10^{3}$ \\
\hline August & $1.1 \times 10^{3}$ & $>2.4 \times 10^{3}$ & $>2.4 \times 10^{3}$ & $>2.4 \times 10^{3}$ & $>2.4 \times 10^{3}$ & $>2.4 \times 10^{3}$ & $1.1 \times 10^{3}$ \\
\hline September & $1.1 \times 10^{3}$ & $>2.4 \times 10^{3}$ & $>2.4 \times 10^{3}$ & $>2.4 \times 10^{3}$ & $>2.4 \times 10^{3}$ & $>2.4 \times 10^{3}$ & $>2.4 \times 10^{3}$ \\
\hline October & $>2.4 \times 10^{3}$ & $>2.4 \times 10^{3}$ & $>2.4 \times 10^{3}$ & $>2.4 \times 10^{3}$ & $>2.4 \times 10^{3}$ & $>2.4 \times 10^{3}$ & $1.1 \times 10^{3}$ \\
\hline November & $>2.4 \times 10^{3}$ & $>2.4 \times 10^{3}$ & $>2.4 \times 10^{3}$ & $>2.4 \times 10^{3}$ & $>2.4 \times 10^{3}$ & $>2.4 \times 10^{3}$ & $>2.4 \times 10^{3}$ \\
\hline December & $1.1 \times 10^{3}$ & $>2.4 \times 10^{3}$ & $>2.4 \times 10^{3}$ & $>2.4 \times 10^{3}$ & $>2.4 \times 10^{3}$ & $>2.4 \times 10^{3}$ & $1.1 \times 10^{3}$ \\
\hline
\end{tabular}


The US Department of Interior, Federal Water Pollution Control Administration in its 1968 report on water quality stated the tolerable limit for recreation purposes up to $1.0 \times 10^{3} / 100 \mathrm{ml}$ of total and $2.0 \times 10^{2} / 100 \mathrm{ml}$ of faecal coliforms. The World Health Organization (WHO) allows less than 10 coliform per $100 \mathrm{ml}$ as maximum for small community supplies. WHO European and International Standards for drinking water require that no coliform should be present in $90 \%$ samples in year ${ }^{13-14}$. In our observation the total and faecal coliform counts in all the sampling stations were greater than these recommended standards. The range of coliforms found in our study was clearly a case of very heavy pollution.

Salmonellae were isolated from 27 samples. They were found in sewage water as well as in the river water. Salmonella is of great concern in public health and is explained as a prime example of a water and shellfish-transmitted pathogen ${ }^{15}$. It has been suggested that enteric pathogens can frequently become associated with aquatic animals ranging from microscopic invertebrates to aquatic mammals ${ }^{16}$. This result of this present study was similar to that of the study performed by Dondero et al. ${ }^{17}$ who isolated Salmonella from streams and lakes. Salmonellae were also isolated from fresh and estuarine waters by a number of investigators ${ }^{18-19}$. Cherry et al. ${ }^{18}$ also distinguished Salmonella as an index of pollution of surface waters. For that reason the Buriganga River could be distinguished as very much contaminated.

Vibrios were present in 73 samples. The present study supports the suggestion of different studies that vibrios are ubiquitous and abundant in the aquatic environment ${ }^{20-21}$. River water can be a great source of transmission of vibrios into aquatic organisms ${ }^{16}$.

Ammonium oxidizers and nitrite oxidizers were quantified only for the months of February, May and September 2005. Nitrifying bacterial population was very low as compared to the heterotrophic bacteria in our studied sites. Ammonium oxidizers ranged from $1.1 \times 10^{2}$ to $1.1 \times 10^{3} / \mathrm{ml}$ in the sewage lagoon and $2.0 \times 10^{1}$ to $2.2 \times 10^{3} / \mathrm{ml}$ in the samples collected from the Buriganga River. The MPN values of nitrite oxidizers ranged from 1.2 to $2.1 / \mathrm{ml}$ in the sewage lagoon and 1.0 to $2.8 / \mathrm{ml}$ in the sampling locations of the Buriganga River. These chemoautotrophic bacteria get the energy from inorganic compounds available in the water. As organic pollutants overloaded the sampling locations, these autotrophic bacteria might have not got enough support for their growth.

An upstream location (Dhaleswar) was chosen to study the bacterial population and correlate the results with the results of the bacterial population analysis of the downstream locations. It was found that heterotrophic bacteria were found in lesser amounts than that of the downstream locations. The river Buriganga receives large amount of sewage effluents everyday that passes through the downstream of the river. This could be the factor that had great impact on the variation of the results.

Since sewage is a major source of aquatic environmental pollution, its physical, chemical and biological properties have the ability to pollute the environment if it is not properly treated. Among the physical parameters, particularly the temperature is important primarily because it affects aquatic and biological life in the receiving body of water. Higher temperature lowers the dissolved oxygen solubility in water and hence creates problems for survival of fish. The chemical characteristics of the wastewater can adversely affect the environment in many ways. Soluble organics can deplete oxygen levels in streams. Toxic materials can affect food chains. Excessive nutrients can cause eutrophication. Biological characteristics of sewage give indication of the presence of pathogenic organisms. All these information are needed to measure water quality for discharging the treated effluents into water bodies ${ }^{22}$.

It can be suggested that standard secondary and tertiary treatment should be applied for total elimination of pathogenic organisms. Sanitary engineering construction must be well developed. Water quality examination should have to be ideal. Water pollution problems are exceedingly complex, and opinions differ. Many more basic studies are needed to find the most fruitful approaches to a more complete understanding.

\section{Acknowledgements}

Sampling was done with the kind permission of the Managing Director of WASA, Government of Bangladesh.

\section{References}

1. Pelczer MJ, Reid R \& Chan FCS. 1990. Microbiology, $5^{\text {th }}$ edn, pp 785-832. Tata McGraw Hill Publishing Company, New York.

2. Biamon EJ \& Hazen TC. 1983 Survival and distribution of Aeromonas hydrophila in near-shore costal waters of Puerto Rico receiving rum distillery effluent. Water Res. 17: 319-326.

3. Matches JR, Liston J \& Curran D. 1974. Clostridium perfringens in the environment. Appl Microbiol. 28: 655-660.

4. Howington JP, McFeters GA, Barry JP \& Smith JJ. 1992. Distribution of the McMurdo Station sewage plume. Mar Pollut Bull. 25: 324-327.

5. Amin AFMS, Samsuddin SAJ \& Alam MM. 1998. Optimisation of sewage treatment process at Pagla. The Proceedings of the $24^{\text {th }}$ WEDC (The Water, Engineering \& Development Centre) Conference. Islamabad, Pakistan.

6. Cebron A, Berthe T \& Garnier J. 2003. Nitrification and nitrifying bacteria in the lower Seine River and estuary (France). Appl Environ Microbiol. 69(12): 7091-7100.

7. Greenberg AE, Clesceri LS \& Eaton AD. 1998. Standard Methods for the Examination of Water and Wastewater, 20 ${ }^{\text {th }}$ edn, APHA, AWWA, WPCF and WEF. American Public Health Association (APHA), New York.

8. APHA. 1971. Standard Methods for the Examination of Water and Wastewater, $13^{\text {th }}$ edn, APHA, AWWA, WPCF and WEF. American Public Health Association (APHA), Washington DC.

9. Bauman P \& Schubert RHW. 1984. Facultatively anaerobic Gramnegative rods, Family II. Vibrionaceae. In Bergey's Manual of Systematic Bacteriology (Krieg NR \& Holt JG eds), Vol 1, pp 516550. Williams \& Wilkins, Baltimore MD.

10. Matulewich VA, Storm PF \& Finstein MS. 1975. Length of incubation for enumerating nitrifying bacteria present in various environments. Appl Microbiol. 29(2): 265-268. 
11. Garnier J, Billen G \& Servais P. 1992. Physiological characteristics and ecological role of small and large sized bacteria in a polluted river (Seine River, France). Arch Hydrobiol Ergebn Limnol. 37: 83-94.

12. Garnier J, Servais P \& Billen G. 1991. Bacterioplankton in the Seine River: Impact of the Parisian urban effluents. Can J Microbiol. 38: 56-64.

13. WHO. 1970. European Standard for Drinking Water, $2^{\text {nd }}$ edn. World Health Organization, Geneva.

14. WHO. 1971. International Standard for Drinking Water, $2^{\text {nd }}$ edn. World Health Organization, Geneva.

15. Baudart J, Grabulos J, Barusseau JP \& Lebaron P. 2000. Salmonella spp. and faecal coliform loads in coastal waters from a point vs. nonpoint source of pollution. J Environ Qual. 29: 241-250.

16. Venkateswaran K, Takai T, Navarro IM, Nakano H, Hashimoto H \& Siebeling RJ. 1989. Ecology of Vibrio cholerae non-O1 and Salmonella spp. and role of zooplankton in their seasonal distribution in Fukuyama coastal waters, Japan. Appl Environ Microbiol. 55: 1591-1598.
17. Dondero NC, Thomas CT, Khare M, Timoney JF \& Fukui GM. 1977. Salmonella in surface waters of Central Newyork State. Appl Environ Microbiol. 33(4): 791-801.

18. Cherry WB, Hanka JB, Thomason BM, Murlin AM, Biddle JW \& Croom JM. 1972. Salmonellae as an index of pollution of surface water. Appl Microbiol. 24: 334-339.

19. Hendricks CW. 1972. Enteric bacterial growth rates in river water. Appl Microbiol. 24: 168-174.

20. Barbieri E, Falzano L, Fiorentini C, Pianetti A, Baffone W, Fabbri A, Matarrese P, Casiere A, Katouli M, Kuhn I, Mollby R, Bruscolini F \& Donelli G. 1999. Occurrence, diversity, and pathogenicity of halophilic Vibrio spp. and non-O1 Vibrio cholerae from estuarine waters along the Italian Adriatic coast. Appl Environ Microbiol. 65: 2748-2753.

21. Denner EBM, Vybiral D, Fischer UR, Velimirov B \& Busse HJ. 2002. Vibrio calviensis sp. nov., a halophilic, facultatively oligotrophic 0.2 micronfilterable marine bacterium. Int J Syst Evol Microbiol. 52: 549-553.

22. Sundstorm DW \& Klei HE. 1969. Wastewater Treatment, pp. 10-19. Prentice-Hall Inc, Englewood Cliffs, New Jersey. 